\title{
Assessment of the effectiveness of forest use in the Republic of Tatarstan
}

\author{
Airat Sabirov ${ }^{1}$, Vaiery Chernykh ${ }^{2}$, Aigul Mukhametshina ${ }^{3, *}$, Nursil Gibadullin ${ }^{3}$, and Azat Minnehanov ${ }^{4}$ \\ ${ }^{1}$ Tatmelioratsia Open Joint-Stock Company, 420073 Kazan, Russia \\ ${ }^{2}$ Volga state technological university, 400005 Volgograd, Russia \\ ${ }^{3}$ Kazan state agricultural university, 420015 Kazan, Russia \\ ${ }^{4}$ Sabinskoe Forestry, 422062 Sabinskiy district, Republic of Tatarstan, Russia
}

\begin{abstract}
As a result of the research work, the structure of the organization of forestry management in the Russian Federation and its constituent entities, acting following the new forest code of the Russian Federation in 2006, was studied. Assessment of the effectiveness of the use of forests in the republic, a multiple correlation analysis was applied. As a result, it was revealed that in the Republic of Tatarstan, the primary income for the use of forests is accounted for by timber harvesting, the bulk of which is accounted for by the use of coniferous forest areas $-81 \%$, soft-leaved, and hard-leaved forests accounted for $14 \%$ and $5 \%$, respectively. Taking into account the share of exploitable forests for the receipt of payments from the lease of forest plots for all types of use (harvesting and collection of non-timber forest resources; hunting; farming; recreational activities; geological exploration of mineral resources; development of mineral deposits; construction, reconstruction and operation of communication lines, roads, pipelines and other linear facilities; payment for the conversion of forest land to non-forest land and the transfer of forest land to lands of other categories) in the Republic of Tatarstan, the structure of forests by farms affects, and on the contribution to payments by type of use, soft-leaved farming brings $78 \%$, hard-leaved $12 \%$ and coniferous $10 \%$.
\end{abstract}

\section{Introduction}

For any constituent entity of the Russian Federation, when planning forest territories, the consideration of natural factors is brought to the fore. These natural factors are the terrain, hydrological and hydrogeological conditions, the geological structure of the landscape, the biodiversity of local flora and fauna (stocks and distribution of plant and animal species of economic and environmental importance), as well as the current presence and condition of forest infrastructure (road transport network, forest management structure and boundaries of functioning economic structures) [1-3]. A complex combination of prevailing natural and economic conditions and their consideration in forest planning contributes to the most efficient organization of the territory, which leads to the rational, multipurpose and sustainable use of forests while ensuring its environmental sustainability, generating revenues to the budget of the Russian Federation and its subjects $[1,4]$.

\section{Objects and research methods}

The purpose of the research is to analyze the management system and assess the effectiveness of the use of forest lands of the Republic of Tatarstan and develop recommendations for its improvement.

The object of the study is the land belonging to the category of the forest fund land, located within the boundaries of the Subject of the Russian Federation the Republic of Tatarstan.

All studies and evaluations are made, taking into account the current legislative and regulatory framework of the Russian Federation.

As the information base, annual reports and reports, statistical data and materials of the Ministry of Forestry of the Republic of Tatarstan on the state and use of forests in the republic, the Ministry of Ecology and Natural Resources of the Republic of Tatarstan were used [5-8].

Analyzing and evaluation of the effectiveness of the using of the territory of the forest fund of the Republic of Tatarstan, the multiple correlation analysis methods were used, which is applied to compare the quantitative relationships of attributes when there are three or more groups in the study $[9,10]$.

As a rule, each factor individually does not determine the phenomena studied in its entirety. Only a set of factors in their relationship can approximately give an idea of the nature of the phenomena studied.

\footnotetext{
* Corresponding author: aigulsafina@yandex.ru
} 


\section{Results and discussion}

The Republic of Tatarstan is a subject of the Russian Federation, where the total area of Tatarstan is $67.847 \mathrm{~km}^{2}$. The length of the republic's territory is 290 $\mathrm{km}$ from north to south and $460 \mathrm{~km}$ from west to east, the bulk of which is occupied by farmland 4.4 million hectares (65\% of the territory of Tatarstan). Forest land accounts for approximately $18 \%$.

According to the order of the Ministry of Natural Resources of Russia dated March 28, 2007 No. 68 "On approval of the list of forest growing zones and forest regions of the Russian Federation", the territory of the Republic of Tatarstan refers to two forest growing zones: 1) a zone of coniferous-deciduous forests and 2) a forest-steppe zone.

Fig. 1 shows the dynamics of changes in the area of land of the forest fund of the Republic of Tatarstan for more than 76 years - there is an increase of 95.5 thousand hectares. It is caused by artificial and natural afforestation of abandoned and inconvenient agricultural lands and further transfer to the category of forest lands.

For the period from 1940 to 2016, the forest area in the Republic of Tatarstan increased from 1062.4 ha to 1231 ha or $1.4 \%$. The trend line shows a moderate tendency to increase the forest area of the Republic of Tatarstan, where the determination coefficient is $\mathrm{R} 2=$ 0.4432 .

The structure of the forest fund lands is very heterogeneous: forest lands predominate $(95.6 \%)$, with $93.6 \%$ of the area covered by forest, and $26.7 \%$ - by artificial plantations. Burned out and lost plantations, valleys, deserts and glades, clearings belong to the lands not covered by forest and makeup $2.0 \%$. Non-forest lands account for $4.4 \%$ of the area, which is represented mainly by the territory necessary for the creation of forest infrastructure (roads, clearings, estates), water bodies and agricultural land.
As of January 1, 2016, according to the State Forest Register, the forest resources are 190.3 million cubic meters. The expanded annual volume of wood harvesting for all types of felling (estimated cut) is 2231.1 thousand cubic meters, including 1404.9 thousand cubic meters for ripe and mature forest stands.

According to Article 10 of the Forest Code of the Russian Federation, forests are divided for their intended purpose into protective, operational and reserve, which meet their requirements in the field of use, protection, protection, and reforestation. The area of exploitable forests of the Republic of Tatarstan is 682.3 thousand hectares $(55.2 \%)$, and protective forests -554.1 thousand hectares $(44.8 \%)$. The average age of plantations is about 48 years [8].

Payments for the use of forests are the primary source of financing for forestry activities in the Republic of Tatarstan. Before the adoption of the Forest Plan of the Republic of Tatarstan in 2007, the total amount of payments for the use of forests amounted to 64888 thousand rubles, of which 48219.1 thousand rubles went to the federal budget and 16668.9 thousand rubles went to the republican budget.

The real source of replenishment of funds for financing forestry activities in the Republic of Tatarstan is the payment for timber sold on the root from the harvesting of ripe and overripe stands.

Short-term use is the primary type of forest use among the loggers of the Republic of Tatarstan, which reflects the percentage of the plan for payments received by the results of the auctions.

Correlation analysis of the use of forests made by 30 forestries in $2007(\mathrm{~N}=30)$ depending on the area of the species structure, the area of species by age structure and the share of production forests shows (Table 1):

- large (close) relationship of payments in the form of cutting areas of ripe conifers $r(n)=0.729165$,

- areas of conifers ripening $\mathrm{r}(\mathrm{n})=0.793368$.

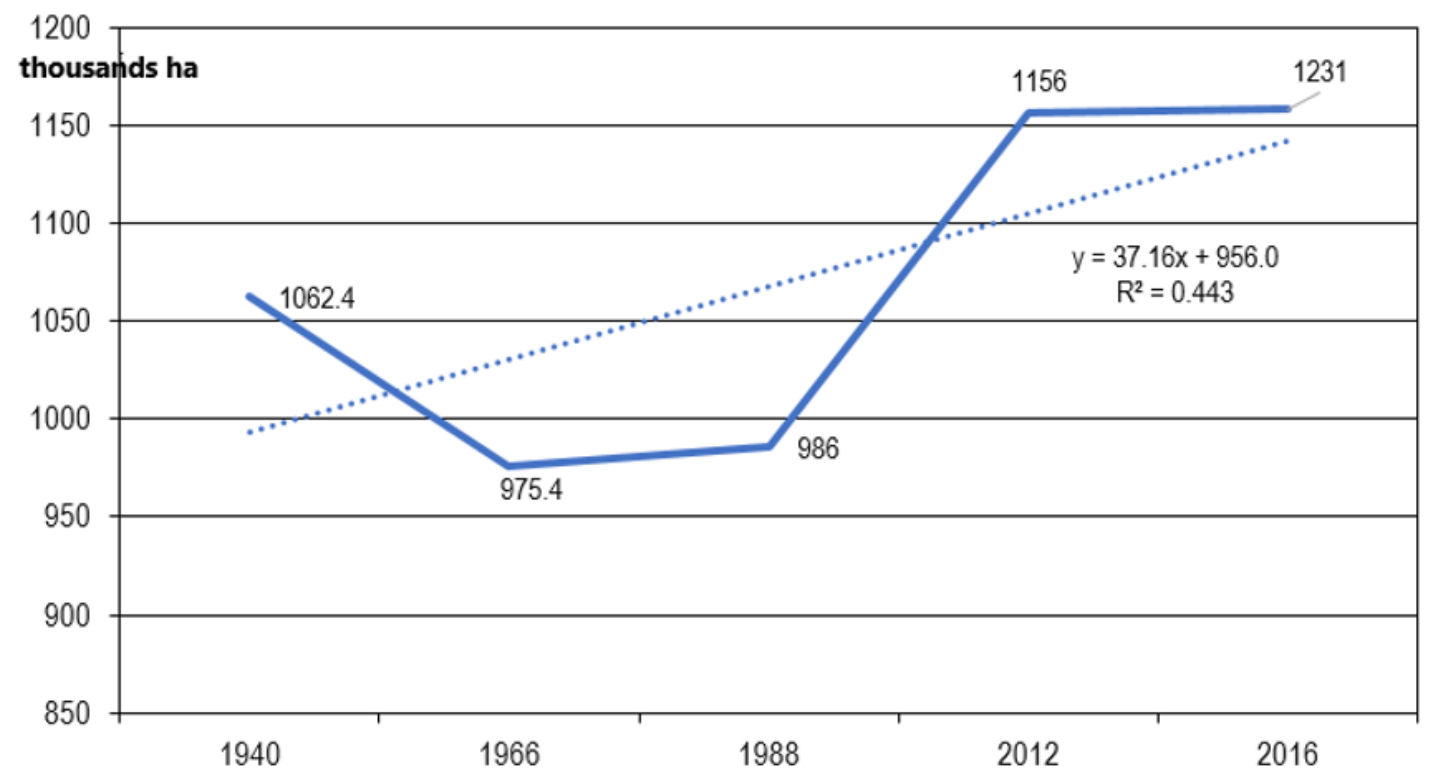

Fig. 1. Dynamics of the forest area of the Republic of Tatarstan for 1940-016, thousand hectares. 
Table 1. Correlation matrix. Marked correlations are significant at $\mathrm{p}<0.05000 \mathrm{~N}=30$ (Random deletion of missing data).

\begin{tabular}{|c|c|c|c|c|c|c|c|c|c|}
\hline $\begin{array}{c}\text { Types of } \\
\text { payments }\end{array}$ & $\begin{array}{c}\mathbf{m} \\
\text { (soft- } \\
\text { leaved) }\end{array}$ & $\begin{array}{c}\mathbf{t v} \\
\text { (hardwood) }\end{array}$ & $\begin{array}{c}\text { xvper } \\
\text { (coniferous } \\
\text { overripe) }\end{array}$ & $\begin{array}{c}\text { xvsp } \\
\text { (coniferous } \\
\text { ripe) }\end{array}$ & $\begin{array}{c}\mathbf{x v p r} \\
\text { (coniferous } \\
\text { churning) }\end{array}$ & $\begin{array}{c}\text { xvcr } \\
\text { (coniferous } \\
\text { mid-season) }\end{array}$ & $\begin{array}{c}\text { Xv m } \\
\text { (coniferous } \\
\text { young } \\
\text { growths) }\end{array}$ & $\begin{array}{c}\text { Xv } \\
\text { (total } \\
\text { coniferous) }\end{array}$ & Summ \\
\hline taxes & -0.0969 & -0.2965 & 0.1618 & $\mathbf{0 . 7 2 9 2}$ & $\mathbf{0 . 7 9 3 4}$ & $\mathbf{0 . 5 9 0 4}$ & $\mathbf{0 . 3 7 9 3}$ & $\mathbf{0 . 6 1 6 7}$ & 0.0785 \\
\hline rent & -0.1279 & -0.1455 & -0.0643 & $\mathbf{0 . 3 6 1 9}$ & 0.0809 & 0.2737 & -0.0758 & 0.1016 & -0.1072 \\
\hline taxes_pr & -0.0443 & 0.0380 & -0.0572 & -0.0824 & 0.2174 & 0.0617 & 0.1314 & 0.1274 & 0.0200 \\
\hline rent_pr & 0.0443 & -0.0380 & 0.0572 & 0.0824 & -0.2174 & -0.0617 & -0.1314 & -0.1274 & -0.0200 \\
\hline
\end{tabular}

One hundred percent receipt of payments for the use of forest in 2007 in the Republic of Tatarstan ensured the use of coniferous forest areas. Soft-leaved and hardleaved forests accounted for 17 and $6 \%$ of payments for the use of forests, respectively.

In the context of the total area of forest districts on the payments received from the lease of forest plots, the first place is firmly held by the lease of areas of softleaved species. The second place in budget revenues belongs to payments for renting coniferous areas. The third place in budget revenues belongs to the lease of hardwood species.

The forest structure by species composition and forestry in the republic is very diverse. However, microclimatic zones can come to common denominators. So in the Pre-Kama region, coniferous (25-52\%) and soft-leaved (35-50\%) species predominate. In the PreVolga region, the predominant species are hard-leaved (25-51\%) and soft-leaved species (35-45 \%). In Zakamye, the predominant species are soft-leaved (60-83\%), and coniferous and hard-leaved species occupy second and third places (which makes it possible to characterize them as secondary).

The total area of forests provided for use as of January 1,2017 , is $303,720.3$ ha $(25.3 \%$ of the entire forest fund). Of this area, 218,809.6 ha were leased, $84,730.0$ ha for permanent, unlimited use and 180.7 ha for gratuitous use.

Table 2. Multiple correlation matrix for analysis of rental structure for 2016 in the context of forestries of the Republic of Tatarstan

\begin{tabular}{|c|c|c|c|c|c|c|c|c|c|c|c|c|c|c|}
\hline Indicators & $\begin{array}{l}\text { Sum } \\
\text { ap }\end{array}$ & $\mathbf{z d}$ & oh & agr & nir & rec & geo & vod & lin & prom & Saz & na & nda & nl \\
\hline $\begin{array}{c}\text { Sumap } \\
\text { (amount of rental } \\
\text { payments)) }\end{array}$ & 1.000 & 0.056 & -0.050 & 0.103 & -0.020 & 0.726 & 0.645 & 0.539 & 0.631 & 0.030 & 0.029 & 0.645 & 0.741 & 0.056 \\
\hline $\begin{array}{c}\text { zd(harvesting of } \\
\text { trees) }\end{array}$ & 0.056 & 1.000 & -0.064 & -0.029 & -0.050 & -0.033 & 0.013 & -0.037 & 0.036 & 0.072 & 0.450 & -0.055 & -0.042 & -0.351 \\
\hline oh(hunting) & -0.050 & -0.064 & 1.000 & -0.103 & -0.082 & -0.136 & 0.089 & -0.187 & -0.137 & 0.290 & 0.821 & -0.097 & -0.091 & 0.264 \\
\hline $\begin{array}{l}\text { agr(agricultural } \\
\text { activity) }\end{array}$ & 0.103 & -0.029 & -0.103 & 1.000 & -0.131 & 0.002 & 0.132 & 0.022 & 0.226 & -0.049 & -0.095 & -0.111 & -0.072 & -0.140 \\
\hline $\begin{array}{c}\text { nir(research } \\
\text { activity) }\end{array}$ & -0.020 & -0.050 & -0.082 & -0.131 & 1.000 & 0.069 & -0.130 & 0.643 & -0.103 & -0.038 & -0.109 & 0.016 & -0.009 & -0.035 \\
\hline rec(recreation) & 0.726 & -0.033 & -0.136 & 0.002 & 0.069 & 1.000 & -0.049 & 0.735 & 0.264 & -0.049 & -0.133 & 0.965 & 0.969 & 0.220 \\
\hline $\begin{array}{l}\text { geo(geological } \\
\text { study of the } \\
\text { subsoil) }\end{array}$ & 0.645 & 0.013 & 0.089 & 0.132 & -0.130 & -0.049 & 1.000 & -0.050 & 0.563 & 0.079 & 0.144 & -0.114 & 0.019 & -0.118 \\
\hline $\begin{array}{l}\operatorname{vod}(\text { hydraulic } \\
\text { construction) }\end{array}$ & 0.539 & -0.037 & -0.187 & 0.022 & 0.643 & 0.735 & -0050 & 1.000 & 0.246 & -0.086 & -0.185 & 0.646 & 0.654 & 0.105 \\
\hline $\begin{array}{c}\operatorname{lin}(\text { construction of } \\
\text { linear facilities) }\end{array}$ & 0.631 & 0.036 & -0.137 & 0.226 & -0.103 & 0.264 & 0.563 & 0.246 & 1.000 & -0.119 & -0.094 & 0.135 & 0.234 & -0.041 \\
\hline $\begin{array}{c}\mathbf{s a z}(\text { total area of } \\
\text { leased forest land, } \\
\text { ha) }\end{array}$ & 0.029 & 0.450 & 0.821 & -0.095 & -0.109 & -0.133 & 0.144 & -0.185 & -0.094 & 0.484 & 1.000 & -0.115 & -0.089 & -0.003 \\
\hline $\begin{array}{c}\text { na(number of } \\
\text { tenants) }\end{array}$ & 0.645 & -0.055 & -0.097 & -0.111 & 0.016 & 0.965 & -0.114 & 0.646 & 0.135 & -0.027 & -0.115 & 1.000 & 0.988 & 0.265 \\
\hline $\begin{array}{c}\text { nda(number of } \\
\text { leases) }\end{array}$ & 0.741 & -0.042 & -0.091 & -0.072 & -0.009 & 0.969 & 0.019 & 0.654 & 0.234 & 0.019 & -0.089 & 0.988 & 1.000 & 0.248 \\
\hline $\begin{array}{c}\text { nl(forestry } \\
\text { number) }\end{array}$ & 0.056 & -0.351 & 0.264 & -0.140 & -0.035 & 0.220 & -0.118 & 0.105 & -0.041 & -0.056 & -0.003 & 0.265 & 0.248 & 1.000 \\
\hline
\end{tabular}

Based on the database, a correlation analysis of the rent structure for 2016 in the Republic of Tatarstan was carried out, and statistical indicators of payments for the use of forest land as a lease were established.
Correlation analysis of payments of rent types for the use of forest lands made by 27 forestries in 2016 ( $\mathrm{N}=$ 27) depending on 13 indicators shows (Table 2): 
- large (close) relationship between the amount of rental payments (Sum ap) with recreational activities $(r e c)-r(n)=0.726$, the number of rental agreements (nda) $-\mathrm{r}(\mathrm{n})=0.741$. A large (close) relationship between payments for activities in the hunting sector (oh) and the total area of rented forest land (Saz, ha), where $r(n)=0.821$; between recreational activities (rec) and construction of water bodies, hydraulic structures $($ vod $)-r(n)=0.735$.

- very close relationship of recreational activities (rec) with the number of tenants (na) $-\mathrm{r}(\mathrm{n})=0.965$ and the number of lease agreements (nda) $-r(n)=0.969$. Also, a very close relationship was established between the number of tenants (na) and the number of lease agreements $(\mathrm{nda})-\mathrm{r}(\mathrm{n})=0.988$.

Based on the obtained correlation analysis data, a model of the dependence of payments for recreational activities between the total area of leased land (Saz) and the number of lease agreements (nda) is constructed (Fig. 2).

The share of the lease of forest plots for "Recreational Activities" is $17.76 \%$ of the total "Amount of payments for the lease of forest plots" (Sumap). As the model in Figure 2 shows, payments for "Recreational Activities" are very carefully dependent on the total lease area (Saz) and the number of lease agreements (nda), where $r=0.97$.
Of no small importance is the construction of a model of rental payments for the implementation of the construction of water bodies, hydraulic structures (vod), which is presented in Fig. 3.

The share of the lease of forest plots for "Construction and operation of reservoirs and other artificial water bodies, hydraulic structures, and special ports" is $1.28 \%$ of the total "Amount of payments for the lease of forest plots" (Sum ap). Based on the statistical analysis of the data, a model was built that established a significant relationship between rental payments in "construction of water bodies, hydraulic structures" (vod) and "total rental area" (Saz) and "number of rental agreements" (nda), where $r=0.66$.

Of considerable interest is the modeling of the dependence of "Amounts of lease payments for forest plots" (Sum ap) on the "total lease area" (Saz) and "the number of lease agreements" (nda) (Fig. 4).

Simulation of the dependence "Amounts of payments for the lease of forest plots" (Sum ap) established a substantial (close) relationship $r=0.74$ from the "total lease area" (Saz) and the "number of lease agreements" (nda).

Therefore, the leadership of the Ministry of Forestry of the Republic of Tatarstan needs to increase its area and the number of lease agreements to increase the income from the lease of forest plots.

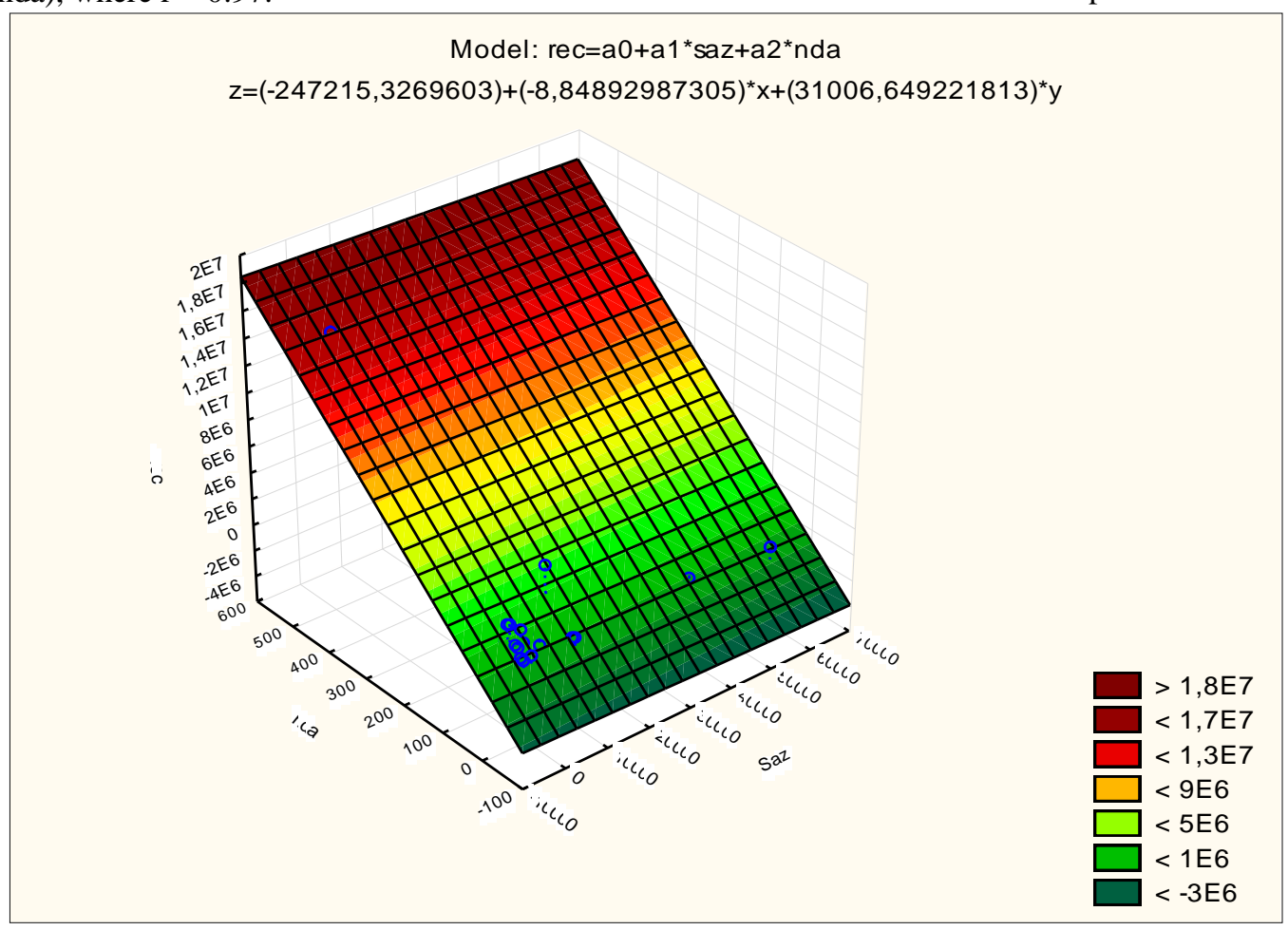

Fig. 2. Recreational activity rental model (rec). 


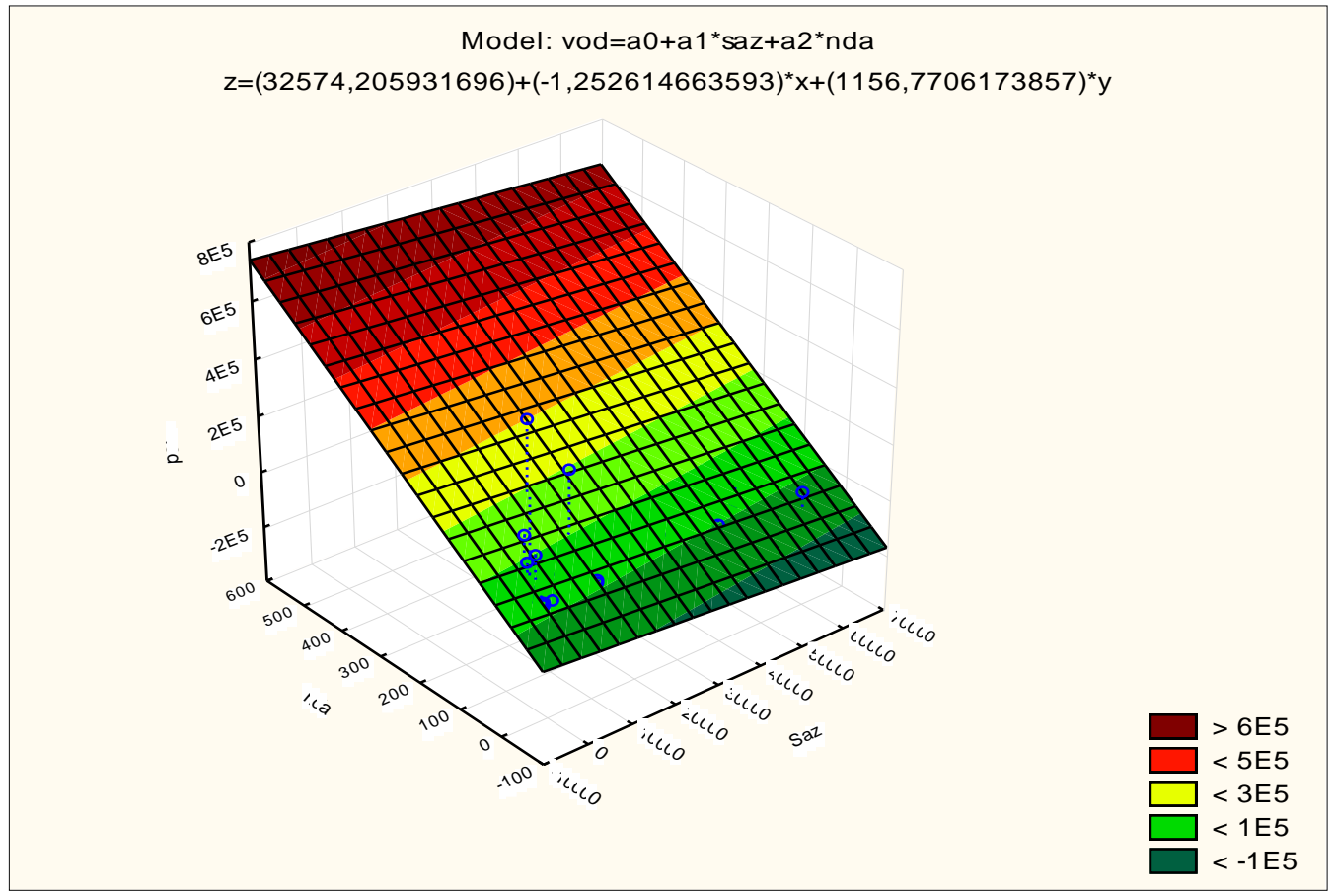

Fig. 3. The model of rental payments in the construction of water bodies, hydraulic structures (vod), $r=0.66$.

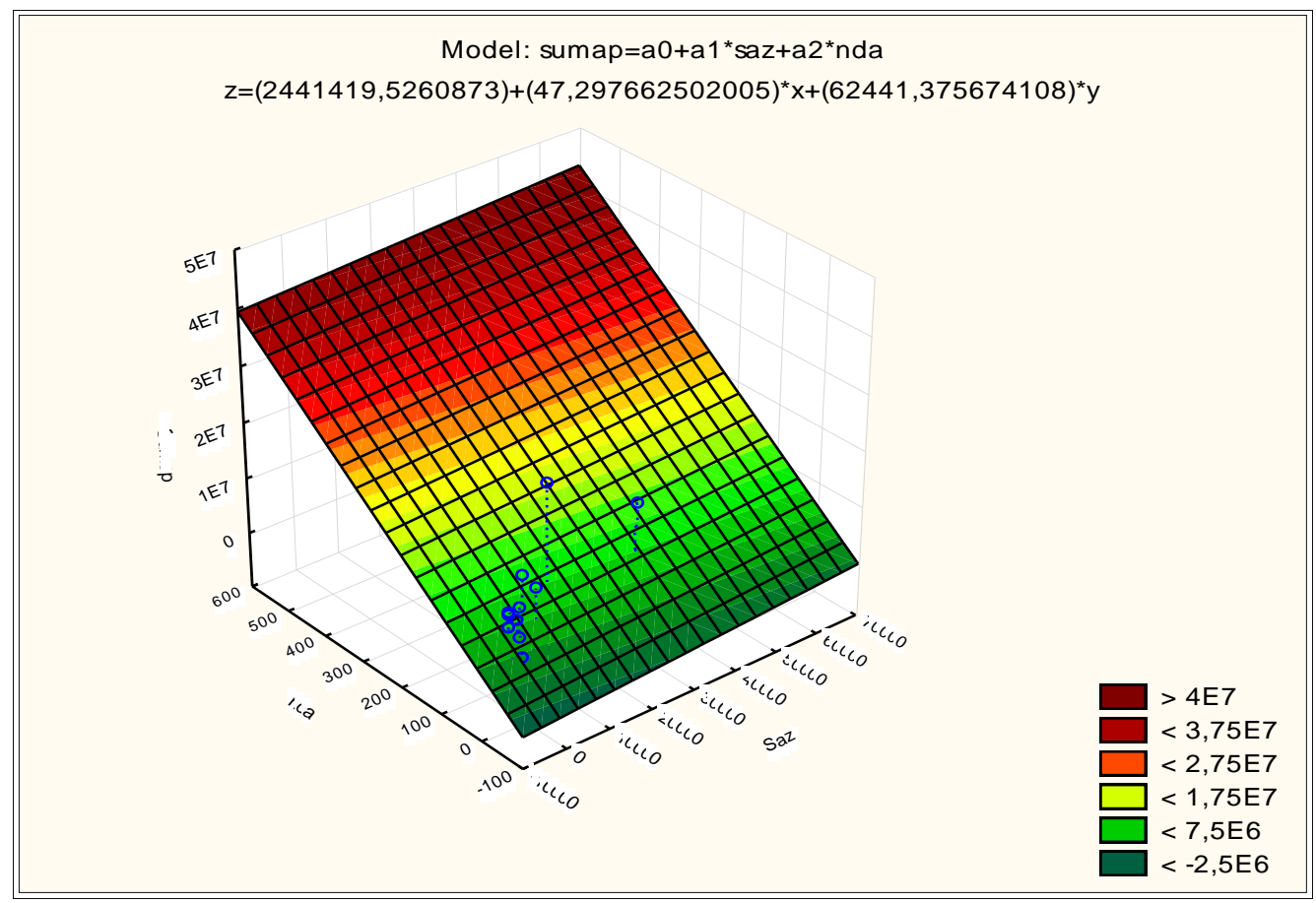

Fig. 4. Model of the dependence of "Amounts of payments for the lease of forest plots" (Sumap) on the "total lease area" (Saz) and "the number of lease agreements" (nda).

\section{Conclusion}

As a result, it was revealed that in the Republic of Tatarstan, the primary income for the use of forests is accounted for by timber harvesting, the bulk of which is accounted for by the use of coniferous forest areas $81 \%$, and soft-leaved and hard-leaved forests account for 14 and $5 \%$, respectively. Payments come from the lease of forest plots for all types of use, which are harvesting and collection of non-timber forest resources; hunting management; farming; recreational activities; geological exploration of mineral resources, development of mineral deposits; construction, reconstruction and operation of communication lines, roads, pipelines and other linear facilities; payment for the transfer of forest land to non-forest land and the transfer of forest land to lands of other categories. Taking into account the share of exploitable forests, the forest structure by farms affects the payments received 
from the lease of forest plots for all types of use in the Republic of Tatarstan, and on the contribution to payments, soft-leaved farming brings $78 \%$, hardwood $12 \%$, and coniferous $10 \%$.

Consequently, the management of the Ministry of Forestry of the Republic of Tatarstan and forestries in order to increase the efficiency of forestry and increase the income from the use of forests must take into account the structure of forests by tree species and, in the future, justify reforestation by target tree species depending on the type of forest use.

\section{References}

1. L.V. Chernykh, Criteria for a potential reforestation method in a forest area, in Scientific progress - the creativity of young people: a collection of scientific papers of the Int. Youth Sci. Conf. on Natural Sci. and Technol., in 3 parts, Part 3, 107-109 (PSTU, Yoshkar-Ola, 2014)

2. W. B. Smith, P. D. Miles, J. S. Vissage, Forest resources of the United States, 2002 (U.S. Department of Agriculture, St. Paul, Minnesota, 2004)

3. D.M. Vorozhtsov, N.A. Vlasova, Mathematical modeling of forest ecosystems: The course of lectures (Volga State Technological University, Yoshkar-Ola, 2015)
4. A.M. Sabirov, D.I. Fayzrakhmanov, A.A. Nazirov, A.R. Minnikhanov, F.G. Burganov, Issues of effective forest management and forest management in the Republic of Tatarstan Bull. of the Kazan State Agrar. Univer. 2(40), 100-104 (2016)

5. A.G. Gayanov, Forests and forestry Tatarstan (Idel Press, Kazan, 2001)

6. Forest Plan of the Republic of Tatarstan (MLH RT, Kazan, 2009)

7. V.V. Pechatkin, The evolution of forest management and reforestation in Russia: myths and reality Economic and social changes: facts, trends, forecast 2, 161-170 (2013)

8. W.B. Cohen, T.K. Maiersperger, S.T. Gower, D.P. Turner, An improved strategy for regression of biophysical variables and Landsat ETM+ data Remote Sensing of Environment 84, 561-571 (2003)

9. Forestry regulations of the Suburban Forestry of the Ministry of Forestry of the Republic of Tatarstan (MLH RT, Kazan, 2013)

10. State of Finland's forest 2011: Based on the Criteria and Indicators of Sustainable Forest Management (Forest research institute (Metla), Ministry of agriculture and forestry, Helsinki, 2011) 